Pinisi Business Administration Review

Vol. 3, No. 1, March 2021, Pages 1-8

ISSN (Print): 2656-6524

ISSN (Online) : 2775-7102

Homenage: httb://ois.unm.ac.id/index.pho/pbar/index

\title{
Efforts to Improve Student Understanding and Learning Outcomes through the Discovery Learning Learning Model
}

\author{
Arsin Junus \\ SDN Inpres Tompudau' Banggai Kepulauan \\ (Received: 28 Oktober 2020; Revised: 14 January 2021; Published: 28 March 2021)
}

\begin{abstract}
To create an attractive learning atmosphere, a teacher needs an approach that is a discovery learning model in the learning process. The purpose of this study was to improve learning understanding and learning outcomes of Inpres Tompudau students in natural science learning material vegetative propagation of plants through the application of discovery learning models. The research method used is classroom action research consisting of planning, acting, observing, and reflecting through two cycles. Data collection techniques, namely observation, tests, and documentation. The data analysis technique uses qualitative and quantitative data techniques with indicators of success seen from an increase in the minimum completeness criteria (KKM) for science subjects for Grade VI students of SDN Inpres Tompudau Semester 1 of the 2019/2020 academic year. Students can be said to be completing individually in learning if they meet the specified KKM value standards if the specified KKM standard is 65 and the student exceeds that value then it can be ascertained that the student is complete, and classically $85 \%$ of the total is declared complete learning and $85 \%$ of the number stated an increase in understanding of learning. The results showed that the use of discovery learning models could improve the understanding and learning outcomes of Grade VI students of SDN Inpres Tompudau regarding the vegetative propagation of plants in the first semester of the $2019 / 2020$ academic year.
\end{abstract}

Keywords: Understanding, Learning Outcomes, Plant Breeding, Discovery Learning.

Copyright ( 2021 Universitas Negeri Makassar. This is an open access article under the CC BY license (http://creativecommons.org/licenses/by/4.0/)

\section{INTRODUCTION}

Education is a very important thing to pay attention to at this time (Cebrián \& Junyent, 2015; Shulla et al., 2020; Shutaleva et al., 2020). Education is not just a discourse to shape young people to become a competent generation, but education emphasizes how this process can be applied. Education is an interactive process that encourages learning events (Niswaty \& Arhas, 2019; Suprianto et al., 2020). Because with learning, there will be physical and mental development of students (Dimyati, 2013)

The learning process is an effort to change behavior while learning as an understanding of mental or psychological learning takes place in active interaction with the environment and results in changes in attitudes in knowledge and understanding, skills and values, and attitudes. 
(Suprihatiningrum, 2013). Based on this understanding, it can be said that learning in addition to requiring concepts also requires practical action. The low quality of education in Indonesia, which is evident from the lagging progress in the fields of science and technology as well as the economy, is a problem that is quite complex to solve. Improvements to catch up with Indonesia from other developed countries need to be done, especially in the education sector, because education can be a reflection of the quality of a person and a country. (Guo et al., 2019; Nasrullah et al., 2018; Neupane, 2019; Sinakou et al., 2018). Based on the results of observations made on science learning in class VI SDN Inpres Tompudau, two important aspects can be seen during the learning process, namely, the teaching process carried out by the teacher and the learning process carried out by students. Problems that occur in the learning process affect student learning outcomes because when learning students prefer to rely on explanations from their teachers without looking for information to build their knowledge. The results of the formative test in the initial study of natural science subject matter vegetative reproduction, it turned out that only $25 \%$ or 5 of the 20 students reached the level of mastery of the material $85 \%$ and above or scored above the KKM of 65 and the level of learning understanding which showed the number $35 \%$ or 7 students of the total number of students as many as 20 . For this reason, teachers need to study and consider the problem of appropriate teaching methods that are appropriate to the child's level of development.

Various attempts have been made by the teacher in making new learning strategies that empower students, which do not require memorizing facts, but strategies that encourage students to construct knowledge in the minds of the students themselves. To create an attractive learning atmosphere, a teacher needs an approach that is a discovery learning model in the learning process. The discovery learning model can help to learn activities take place well so that learning objectives can be achieved properly. Learning by using the discovery learning model always tries to make students discover for themselves the concepts of the material being studied. Students are programmed to always be mentally and physically active. The material presented by the teacher is not just notified and accepted by students. Students are conditioned in such a way that they gain various experiences to "discover for themselves" concepts planned by the teacher and assisted with a little guidance from the teacher. In this way, they will acquire and store the concept better.

To be able to improve student learning outcomes, teachers must be able to create an attractive learning atmosphere. One of them is to use a discovery learning model that can provide students with a new atmosphere in the learning process. Student activities in learning using the discovery learning model include students completing assignments in groups, trying to find the concept of material being studied in groups, and students expressing what is obtained in these activities.

\section{RESEARCH METHOD}

This type of research used in this research is classroom action research, (Arikunto, 2010). The implementation of this research uses Kurt Lewin's research model which develops research on the four components of classroom action research, namely (1) planning, (2) action, (3) observation, and (4) reflection, where the rigorous relationship of these four elements is seen. as one cycle (Arikunto, 2002) 
Arsin Junus; Efforts to Improve Student... 3

Data collection in this study was carried out using observation, testing, and documentation techniques, (Sukmadinata, 2005). The data analysis technique used qualitative and quantitative data analysis techniques. The success indicator is determined if the specified KKM standard is 65 and the student exceeds this value, it can be ascertained that the student is complete, and classically $85 \%$ of the total study completes and $85 \%$ of the number is declared to have increased their learning understanding.

\section{RESULT AND DISCUSSION}

\section{RESULT}

\section{Improved Learning Outcomes}

The use of the discovery learning method will be very helpful in improving student learning outcomes, this is evident from the learning outcomes given in each cycle has increased where the average value in the initial study is $\mathbf{5 6}$ and the first cycle the average value obtained by students is 64 and at In cycle II, the average value obtained by students was 76 . The number of students who completed the initial condition was 5 students $(25 \%)$, increasing in the first cycle by 10 students (10\%) and in the second cycle to 19 students $(95 \%)$. Recapitulation of students' formative test results from initial conditions, cycle I to cycle II can be seen in Table 1.1 below.

Table. 1.1

Value of Formative Test Results Initial Findings, Cycle I and Cycle II

\begin{tabular}{llccccc}
\hline \multirow{2}{*}{ No } & \multirow{2}{*}{ Learning } & \multicolumn{5}{c}{ Student achievement } \\
\cline { 3 - 7 } & & $\begin{array}{c}\text { Average } \\
\text { value }\end{array}$ & $\begin{array}{c}\text { Complete } \\
\text { d }\end{array}$ & $\boldsymbol{\%}$ & Not yet & \% \\
\hline 1. & Early & 56 & 5 & 25,00 & 15 & 75,00 \\
2. & Cycle I & 64 & 10 & 50,00 & 10 & 50,00 \\
3. & Cycle II & 76 & 19 & 95,00 & 1 & 5,00 \\
\hline
\end{tabular}

Source: Results of Data Processing

To clarify the increase in student learning completeness and the decrease in student learning completeness can be seen in bar chart 1.1 below:

Picture. 1.1

Graph of increasing student learning completeness based on the results of formative tests at the initial convention, cycle I and II

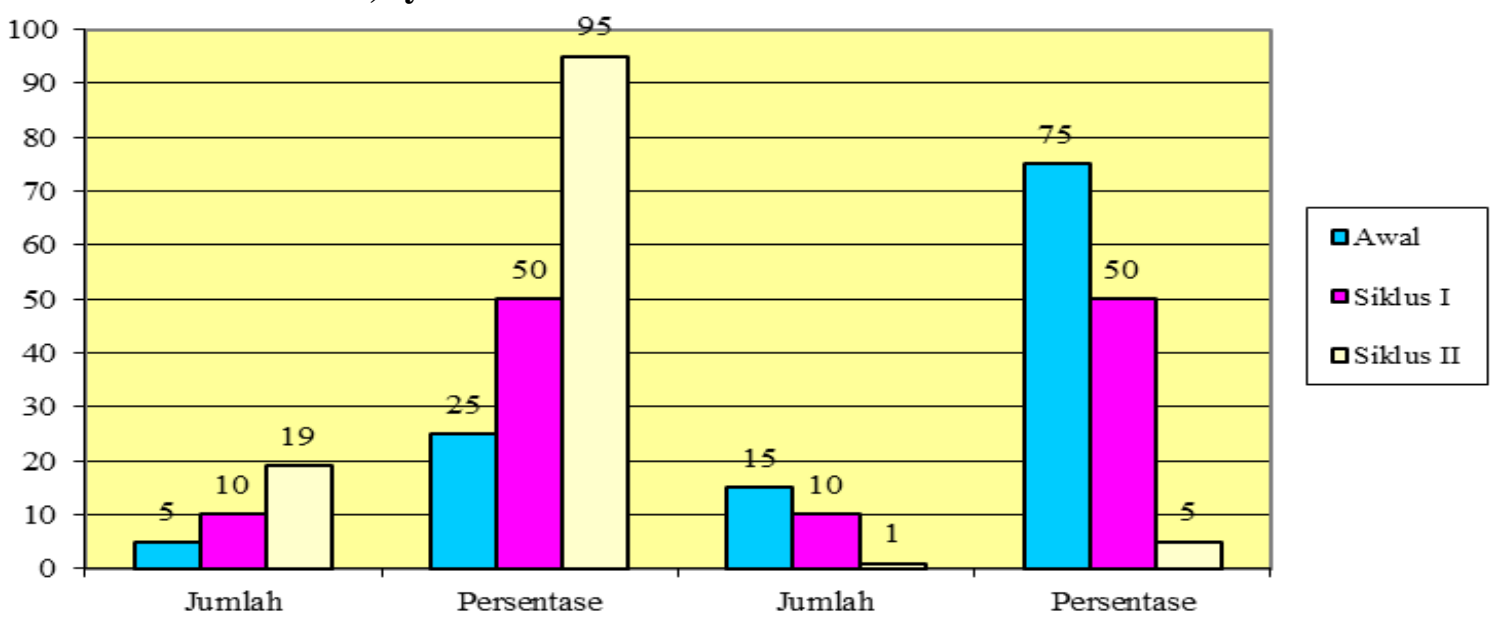




\section{Pinisi Business Administration Review \\ Volume 3 Number 1, Marchh 2021. Pages 1-8}

The explanation of the increase in the average value of learning outcomes in science learning material vegetative natural plant breeding with the application of the discovery learning method shows a significant increase where the average value in the initial conditions is 56.00 and the first cycle the average value obtained students were 64.00 and in cycle II the average value obtained by students was 76.00 . The increase in the average value of student learning outcomes in graphical form is shown in Figure 1.2 below:

\section{Picture. 1.2}

Graph of the Increase in the Average Value of Student Learning in Cycles I and II

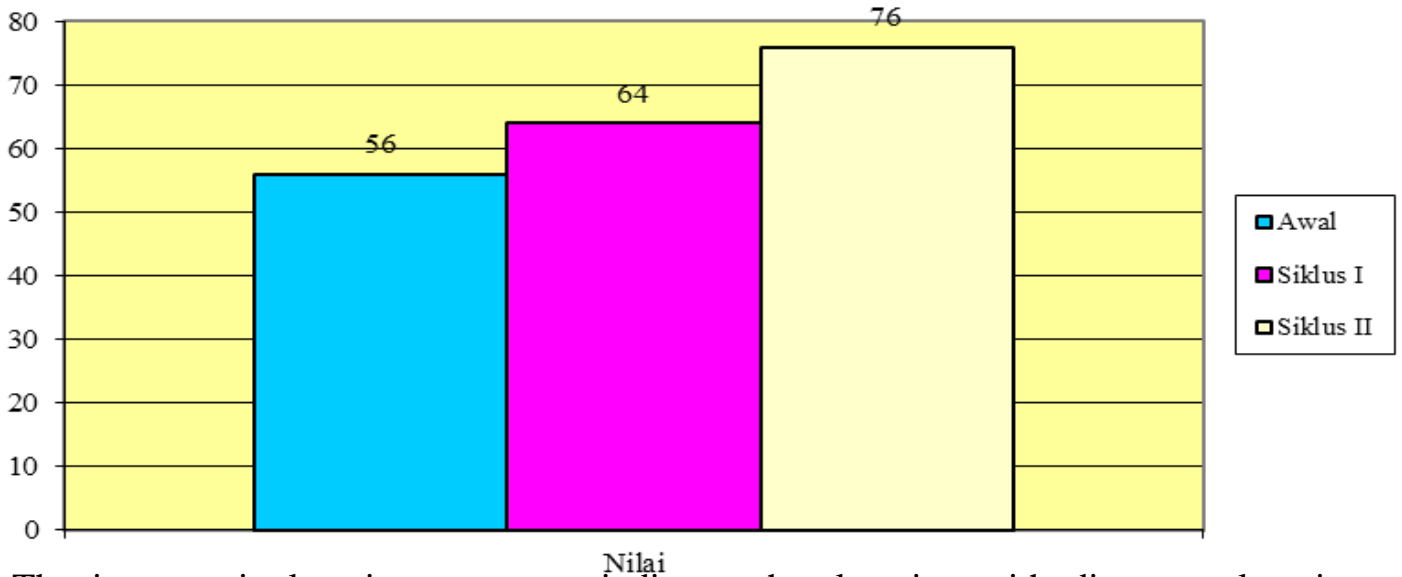

The increase in learning outcomes indicates that learning with discovery learning methods can improve student learning outcomes. This is because this learning is designed so that students can learn to form their knowledge both individually and in groups with the help of the instructions given. The learning pattern of discovery learning method places students as subjects in active learning to build knowledge through investigations to solve problems based on certain stages.

This is following the basic concepts and characteristics of discovery learning which are stated in which learning can be interpreted as a series of activities that emphasize the process of solving problems faced scientifically. Learning by applying the discovery learning method is a series of learning activities, meaning that in its implementation there are some activities that students must do. Students not only take notes and memorize material, but students actively think, communicate, seek and process data and finally conclude. Learning activities are directed to solve problems, meaning that without problems, there is no learning process. Problemsolving is done by using a scientific thinking approach. Where the thinking process is carried out empirically, which is based on clear and systematic data and facts.

In connection with efforts to improve student learning outcomes in science subjects, the material of natural vegetative propagation is a very urgent need, therefore one of the appropriate learning models is the learning model which emphasizes providing wider learning opportunities for students to obtain as well as developing knowledge, attitudes, values and social skills. In this learning, students not only learn and receive subject matter but can learn from other students and also from the media and environment and are required to be able to learn independently and think critically. With the discovery learning method, it can create learning that provides 
Arsin Junus; Efforts to Improve Student... $\mid 5$

opportunities for students to explore, seek and find information so that students' knowledge is more developed and can think critically. So this discovery learning method can help students develop their understanding and attitudes and improve better and meaningful learning outcomes and gain direct and real experience.

The improvement of student learning outcomes in natural science learning material vegetative reproduction of plants in each action cycle shows that learning with the discovery learning approach can improve students' abilities. This is because learning with the discovery learning approach can train the activity to get used to analyzing a problem with various alternatives and the discovery learning approach also conditions students to think critically logically and systematically so that the level of mastery of learning material will increase.

\section{Improved learning comprehension}

The success of the learning improvement process is not only seen from the increase in learning outcomes or formative test scores. Students' understanding of learning during the learning process is also an indicator of success in the learning process. Student activity data were obtained from the observation sheet that had been filled in by the observer during the learning improvement. The focus of observation is focused on aspects of being able to answer, want to ask questions, and be active in discussion activities. The results of observations on the implementation of learning improvement activities show positive results and are proven by an increase in student activity in each cycle.

In detail, an explanation of increasing student understanding in the learning improvement process is as shown in table 1.2 below:

Table. 1.2

Recapitulation of Observation Results Students' Learning Understanding on Initial Findings, Cycle I and Cycle II

\begin{tabular}{|c|c|c|c|c|c|c|}
\hline \multirow{2}{*}{ No } & \multirow{2}{*}{ Description } & \multirow{2}{*}{$\begin{array}{c}\text { The } \\
\text { number of } \\
\text { students }\end{array}$} & \multicolumn{2}{|c|}{ Students Completed } & \multicolumn{2}{|c|}{ Students Not Completed } \\
\hline & & & Frequency & $\%$ & Frequency & $\%$ \\
\hline 1 & Early & 20 & 7 & 35,00 & 13 & 65,00 \\
\hline 2 & Cycle I & 20 & 13 & 65,00 & 7 & 35,00 \\
\hline 3 & Cycle II & 20 & 20 & 100,00 & 0 & 0,00 \\
\hline
\end{tabular}

It is clear that the increase in student activity during the learning improvement process is as described in Figure 1.3 below:

Picture. 1.3

Graph of Student Completeness Based on the Level of Student Activity in Cycles I and II.

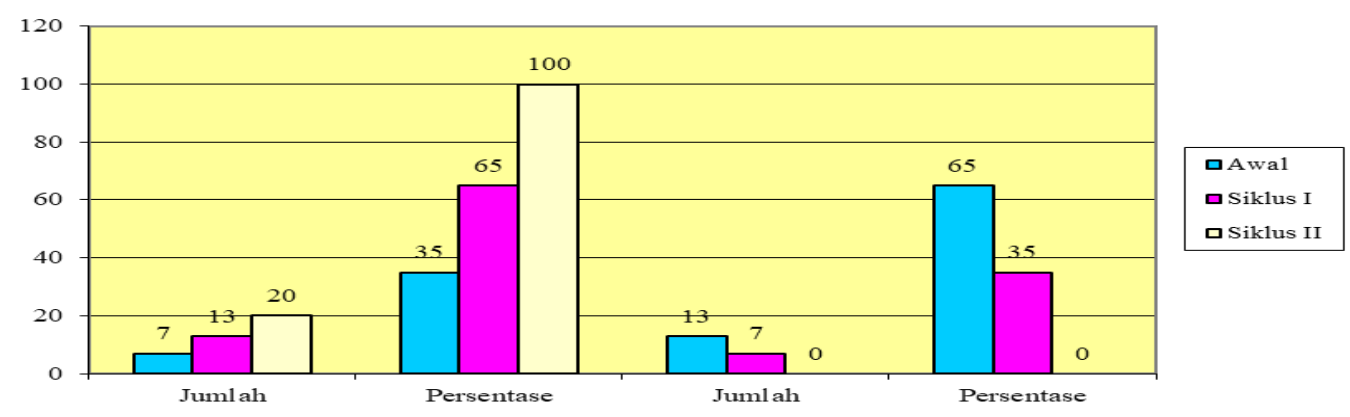


From the results of observations regarding the understanding of these students based on the success criteria for learning improvement, it can be concluded that the learning improvement process is successful because the increase in student activity reaches $100 \%$ from $85 \%$ the minimum limit that has been determined in the success criteria of the learning improvement process. Based on the considerations outlined above, the researchers and observers agreed to decide that learning improvement activities ended in cycle II.

\section{DISCUSSION}

This classroom action research has succeeded in increasing student understanding and learning outcomes. This is evidenced by the acquisition of calculated figures regarding both understanding and student learning outcomes which show an increase in each cycle as described above. This success is due to the learning implementation process by applying the discovery learning method (Bakker, 2018; Ilhan \& Ekber Gülersoy, 2019; Roza et al., 2018). The actions taken in this research problem can be seen based on learning improvement activities that have been carried out from cycle I to cycle II by applying the discovery learning approach model to improve student understanding and learning outcomes in science learning in class VI SDN Inpres Tompudau in natural science learning material on plant propagation in a natural vegetative manner.

Objective conditions based on the results of observations show that activities to improve the understanding of grade VI-grade SDN Inpres Tompudau in the natural science learning process for children's development are still not stimulated. Most children need stimulation to bring up their understanding during science learning. The problems that occur in grade VI students of SDN Inpres Tompudau are due to the teacher's knowledge, the selection and implementation of the science learning methods used are still limited. In this case, the teacher uses the science learning method with its implementation still teacher-centered, giving less opportunity for children to be directly involved.

While participating in science learning, children's understanding will be manifested in the form of finding new concepts, creating new skills and so on that can give birth to things that are original from the child, this shows that understanding is a natural goal in science education.

Science learning activities with the discovery learning method in science learning are carried out with several stages related to the emergence of the characteristics of children's understanding, namely the child's active behavior and creative cognitive. At the stimulation stage, creative active behaviors can appear, such as children's curiosity and a sense of challenge. At the problem formulation stage, creative active behavior of children who dare to take risks can emerge and children's creative cognitive behaviors such as fluency skills can emerge. The data collection stage can appear creative cognitive behavior of children, namely flexible thinking skills (flexible), then at the data analysis stage, original thinking skills can appear, also with elaboration skills at the verification stage and assessment skills (evaluation) at the generalization stage.

The results obtained also show that the science learning method with the discovery learning approach can improve children's understanding ability. Children get more opportunities and dare to express questions and answer questions and express ideas, here children are involved in activities or direct experience (hands-on experience) in learning activities at the stage of collecting data, grouping things according to categories, and children can dare to assess 
Arsin Junus; Efforts to Improve Student... $\mid 7$

and evaluate self in completing the task as well as assessing (friends or teachers) when completing assignments or when solving problems. This method is a method of discovery in which the way of presenting the lesson involves a lot of students in mental processes in the framework of its discovery which requires a lot of thinking activity and sometimes even physical activity.

Based on the explanation above and the results of the implementation of learning improvement data in the form of data from the formative test results in cycle I, cycle II formative tests, and observation data from cycles I and II, it can be concluded that the application of the discovery learning method can improve students' understanding and learning outcomes in science learning. material on natural vegetative propagation in grade VI SDN Inpres Tompudau Semester 1 Academic Year 2019/2020.

\section{CONCLUSION}

Based on the results of data analysis and the findings in this study, it can be concluded that 1) Learning by applying the Discovery Learning learning model can improve student understanding and learning outcomes because the Discovery learning model directs students to find their knowledge. In this study, it is directed to carry out activities independently so that it greatly supports the improvement of understanding and student learning outcomes gradually with guidance to find their knowledge through activities carried out by students repeatedly so that the implementation of the learning process becomes more active and meaningful for students; 2) The application of the discovery learning model in science learning with natural vegetative propagation material is proven to be able to improve students' understanding of learning. This is indicated by the increase in student understanding, which shows that the acquisition in the initial study was only 7 students or $35 \%$, increased to 13 students or $65 \%$ in the first cycle, and also $100 \%$ or 20 students in the second cycle; 3) The application of discovery learning model to science learning material vegetative natural propagation of plants is proven to be able to improve student learning outcomes and completeness. This is also supported by the increase in student learning outcomes from an average of 56 in the initial study, up to 64 in the first cycle, and 76 in the second cycle, with 5 students (25\%) completing the study in the initial study, $50 \%$ or 10 . of students in the first cycle, 19 students or $95 \%$ were declared complete learning and 1 student $(5 \%)$ had not finished their studies, but all the success criteria had been achieved so that the improvement process was declared complete in the second cycle and students who had not completed their studies would be given a remedial program.

\section{REFERENCES}

Arikunto, S. (2002). Metodologi Penelitian Suatu Pendekatan Proposal. 2017.

Arikunto, S. (2010). Prosedur Penelitian Ilmiah. In Rineka cipta, Jakarta.

Bakker, A. (2018). Discovery learning: zombie, phoenix, or elephant? Instructional Science. https://doi.org/10.1007/s11251-018-9450-8

Cebrián, G., \& Junyent, M. (2015). Competencies in education for sustainable development: Exploring the student teachers' views. Sustainability (Switzerland). https://doi.org/10.3390/su7032768

Dimyati, M. dan. (2013). Model-model pengajaran dan pembelajaran. Teaching and Educations. 
Guo, L., Huang, J., \& Zhang, Y. (2019). Education development in China: Education return, quality, and equity. In Sustainability (Switzerland). https://doi.org/10.3390/su11133750

Ilhan, A., \& Ekber Gülersoy, A. (2019). Discovery learning strategy in geographical education: A sample of lesson design. Review of International Geographical Education Online. https://doi.org/10.33403/rigeo.672975

Nasrullah, M., Ilmawati, I., Saleh, S., Niswaty, R., \& Salam, R. (2018). Minat Menjadi Guru Pada Mahasiswa Program Studi Pendidikan Administrasi Perkantoran Fakultas Ilmu Sosial Universitas Negeri Makassar. Jurnal Ad'ministrare, 5(1), 1-6.

Neupane, P. (2019). Policy Framework for Education Development in Nepal. International Education Studies. https://doi.org/10.5539/ies.v13n1p89

Niswaty, R., \& Arhas, S. H. (2019). The Effect of Learning Media on Progress Quality in Office Administration Program in Vocational School Negeri 1 Watampone Bone Regency. Journal of Physics: Conference Series, 1387(1), 12042.

Roza, N., Arnawa, I. M., \& Yerizon. (2018). Practicality of mathematics learning tools based on discovery learning for topic sequence and series. International Journal of Scientific and Technology Research.

Shulla, K., Filho, W. L., Lardjane, S., Sommer, J. H., \& Borgemeister, C. (2020). Sustainable development education in the context of the 2030 Agenda for sustainable development. International Journal of Sustainable Development and World Ecology. https://doi.org/10.1080/13504509.2020.1721378

Shutaleva, A., Nikonova, Z., Savchenko, I., \& Martyushev, N. (2020). Environmental education for sustainable development in Russia. Sustainability (Switzerland). https://doi.org/10.3390/su12187742

Sinakou, E., Boeve-de Pauw, J., Goossens, M., \& Van Petegem, P. (2018). Academics in the field of Education for Sustainable Development: Their conceptions of sustainable development. Journal of Cleaner Production. https://doi.org/10.1016/j.jclepro.2018.02.279

Sukmadinata, S. N. (2005). Metode Penelitian. Bandung: PT Remaja Rosdakarya.

Suprianto, S., Arhas, S. H., \& Mahmuddin, M. (2020). The Effectiveness of Online Learning Amid the COVID-19 Pandemic. Jurnal Ad'ministrare, 7(2), 321-330.

Suprihatiningrum. (2013). Guru Profesional (Pedoman Kinerja, Kualifikasi, dan Kompetensi Guru). In Ar-ruzz Media. 